\title{
PARA “REMOVER OS EMBARAÇOS QUE POSSAM RETARDAR [...] A ADMINISTRAÇÃO DA JUSTIÇA": A CRIAÇÃO DO TRIBUNAL DA RELAÇÃO DE PERNAMBUCO E A COMPOSIÇÃO DE SEUS PRIMEIROS DESEMBARGADORES (1821-1840)
}

\section{TO "REMOVE EMBARASSES THAT MAY DELAY THE ADMINISTRATION OF JUSTICE": THE CREATION COURT OF APPEAL OF PERNAMBUCO AND THE COMPOSITION OF ITS FIRST JUSTICES (1821-1840)}

\section{Jeffrey Aislan Souza Silva*}

Resumo: Entre os séculos XVII e XIX, nobreza e povo da capitania de Pernambuco alegaram dificuldades para recorrer de seus pleitos ao Tribunal da Relação da Bahia, e enviaram solicitações aos monarcas, pedindo a instalação de um Tribunal da Relação na capitania. Em 6 de fevereiro de 1821, o rei D. João VI expediu um alvará, mandando instalar um Tribunal da Relação na vila do Recife. O Tribunal da Relação de Pernambuco recebeu o mesmo regimento dado ao Tribunal da Relação do Maranhão, instituído em 1812. O artigo se propõe a discutir o processo político que promoveu a criação do Tribunal da Relação de Pernambuco. Também trataremos de aspectos da trajetória dos primeiros magistrados nomeados para os bancos do novo Tribunal, assim como as motivações que pautaram as escolhas dos magistrados, por parte da administração régia. Nas considerações finais, além de reforçarmos o argumento apresentado no texto, apontamos para a necessidade de ampliar os estudos sobre os tribunais de justiça, considerando a necessidade de aprofundar a compreensão sobre a atuação dessas instituições na formação do Estado brasileiro.

Palavras-chave: Tribunal da Relação de Pernambuco. Jurisdição. Desembargadores.

Abstract: Between the seventeenth and nineteenth centuries, the nobility and people of the captaincy of Pernambuco claimed difficulties in appealing their claims to the Bahia Court of Appeal, and sent requests to the monarchs, asking for the installation of a Court of Appeal in the captaincy. On February 6, 1821, king D. João VI issued a permit, ordering the installation of a Court of Appeal in the village of Recife. The Court of Appeal of Pernambuco received the same rules as the Court of Appeal of Maranhão, established in 1812. The article proposes to discuss the political process that promoted the creation of the Court of Appeal of Pernambuco. We will also deal with aspects of the trajectory of the first justices appointed to the banks of the new Court, as well as the motivations that guided the choices of magistrates, by the royal administration. In the final remarks, in addition to reinforcing the argument presented in the text, we point to the need to expand the studies on the courts of justice, considering the need to deepen the understanding of the performance of these institutions in the formation of the Brazilian State.

\footnotetext{
* Doutorando em História na Universidade Federal de Pernambuco. Mestre em História pela Universidade Federal Rural de Pernambuco. Graduado em História na Universidade Federal Rural de Pernambuco. E-mail: aislan.jy@gmail.com
} 
Keywords: Court of Appeal of Pernambuco. Jurisdiction. Judges.

Recebido em: 26/04/2021. Aceito em: 29/04/2021. 


\section{INTRODUÇÃO}

Segundo o dicionário de Rafael Bluteau, Relação, entre outros significados, era o "Tribunal de Justiça composto por desembargadores, donde vão por agravo, ou apelação as causas de ante as relações subordinadas, e dos juízes inferiores". Também era o local onde se "relatava" a justiça, onde era exposta a causa judiciária. ${ }^{1}$ As Relações, Tribunais de Justiça, foram introduzidas em Portugal no século XVI, com a criação da Relação do Porto em 1582 (TESTOS, 2018, p. 105), e na América portuguesa entre os séculos XVII e XIX, com a criação da Relação da Bahia em 1609, a Relação do Rio de Janeiro em 1751, a Relação do Maranhão em 1812 e a Relação de Pernambuco, último Tribunal Superior instituído pela coroa portuguesa no Brasil, em 1821. Os Tribunais Superiores foram somados aos aparatos introduzidos paulatinamente pela coroa na América portuguesa, para administrar a justiça. ${ }^{2}$

Entre os séculos XVII e XIX, os moradores da capitania de Pernambuco alegaram significativas dificuldades em recorrer ao Tribunal da Relação da Bahia, e por repetidas vezes, algumas inclusive de forma coordenada, enviaram solicitações aos monarcas, solicitando a criação de um Tribunal da Relação na capitania. requerimento dos súditos pernambucanos foi atendido em 6 de fevereiro de 1821 pelo rei D. João VI, que expediu um alvará autorizando instalar um Tribunal da Relação na vila do Recife. No alvará, o rei afirmou atender a uma solicitação da câmara de Olinda, devido às dificuldades de se recorrer à Relação da Bahia, considerando as grandes distâncias, avultadas despesas e demais inconvenientes. A Relação de Pernambuco

\footnotetext{
1 Silva, Antonio de Morais; Bluteau, Rafael. Diccionario da lingua portugueza composto pelo padre D. Rafael Bluteau, reformado, e accrescentado por Antonio de Moraes Silva natural do Rio de Janeiro, v. 2. Lisboa: Simão Tadeu Ferreira, 1789, p. 588. https://www.bbm.usp.br/pt$\mathrm{br} /$ dicionarios/diccionario-da-lingua-portugueza-recompilado-dos-vocabularios-impressos-ate-agora-enesta-segunda-edi\%C3\%A7\%C3\%A3o-novamente-emendado-e-muito-acrescentado-por-antonio-demoraes-silva/?page_number=1398\#dic-viewer. Acessado em 22 de abril de 2021.

2 O historiador Nuno Camarinhas argumenta que os aparatos de justiça instituídos na América portuguesa foram pautados por uma "raiz marcadamente europeia" (CAMARINHAS, 2018, p. 141). Entre os cargos e funções implementados no território para a administração da justiça, além dos Tribunais da Relação, destacamos os ouvidores, juízes de fora, juízes ordinários, juízes de órfãos e provedores dos defuntos e ausentes. Contudo, a estrutura administrativa implementada pela coroa na América possuía um escopo jurisdicional amplo, o que fazia com que instituições como as Câmaras Municipais, Provedorias e Alfândegas, entre outras, também tivessem atuação de caráter jurisdicional em algumas circunstâncias. $O$ debate sobre essas questões é bastante amplo, composto por uma historiografia extensa e de qualidade. Alguns trabalhos serão citados ao longo do texto, mas de antemão, destaco algumas obras coletivas e individuais que tratam desses cargos e suas atuações no campo da administração da justiça na América portuguesa. (WEHLING; WEHLING, 2004); (SCHWARTZ, 2011); (MELLO, 2015); (ATALLAH, 2016); (BICALHO, ASSIS, MELLO, 2017); (CAETANO, 2018); (MENEZES, 2019); (SIMÕES, 2020).
} 
recebeu o mesmo regimento concedido à Relação do Maranhão, instituída por D. João em 1812. Para os cargos de desembargador, estariam aptos bacharéis formados em leis ou cânones, servidos em lugares de segunda entrância.

Na primeira parte do artigo, dialogando com a historiografia disponível sobre os Tribunais da Relação na América portuguesa, discutiremos as questões referentes a implementação dos Tribunais Superiores na colônia, assim como suas motivações e interesses por parte da administração régia. Posteriormente, trataremos dos aspectos de caráter jurídico e político que permearam a decisão do monarca, ao estabelecer um Tribunal da Relação em Pernambuco. Em sua segunda parte, traremos aspectos da trajetória dos primeiros magistrados nomeados para os bancos do novo Tribunal, assim como as motivações que pautaram as escolhas dos magistrados que assumiram os cargos de desembargadores na instituição. Nas considerações finais, reforçamos nosso argumento e procuramos assinalar a importância e amplitude das funções jurisdicionais atribuídas à Relação de Pernambuco após sua implementação em 13 de fevereiro de 1822, assim como a necessidade de ampliar os estudos sobre a temática no período em tela, para compreendermos as ações dessas instituições no processo de formação do Estado brasileiro.

\section{OS TRIBUNAIS DA RELAÇÃO NA AMÉRICA PORTUGUESA}

As Relações foram implementadas para administração e governo da justiça em nome do rei, "seu presidente natural", e suas estruturas eram análogas à Casa de Suplicação de Lisboa. ${ }^{3}$ As decisões e acórdãos expedidos pelos tribunais tinham força e caráter de uma decisão expedida pelos monarcas, isso fazia com que os despachos remetidos pelos desembargadores não pudessem ser controlados por nenhuma outra instituição, nem mesmo os governadores das capitanias (HESPANHA, 2010, p. 64$65)$.

Para o historiador Stuart Schwartz, pioneiro nos estudos sobre os Tribunais da Relação na América portuguesa, o Tribunal da Relação da Bahia, criado em 1609,

\footnotetext{
${ }^{3}$ A Casa de Suplicação, fixada em Lisboa desde o século XVI, era responsável pelo recurso das decisões tomadas pelas Relações, e, em geral, era o último grau de recurso das decisões jurídicas. A instituição tinha vital importância no caráter jurisdicional do reino, visto que as decisões dadas pelos desembargadores da Casa de Suplicação produziam jurisprudência (HESPANHA, 1994, p. 228-236); (CAMARINHAS, 2014, p. 223-241); (Id., 2010, p. 72-77).
} 
foi instituído para aumentar o controle da jurisdição real na Colônia (SCHWARTZ, 2011, p. 27-40). O Tribunal da Relação foi uma reivindicação dos colonos, que se queixavam dos altos custos que precisavam ser despendidos para recorrerem de seus pleitos aos tribunais existentes em Portugal. Mas o autor reitera que a instituição foi implementada para reafirmar os interesses régios na América portuguesa. Como o único tribunal existente na colônia até 1752, ano de instalação da Relação do Rio de Janeiro, e devido às dificuldades administrativas, baixo número de magistrados nos demais serviços judiciários e especialmente a extensão do território sob sua jurisdição, os desembargadores da Relação da Bahia eram submetidos a um enorme volume de trabalho. Na prática, a extensão das ações dos desembargadores suplantava a esfera jurídica, fazendo com que os magistrados atuassem em funções de governo e administração (Ibid., p. 197-287).

Schwartz ainda argumenta que entre os séculos XVII e XVIII houve recorrência de reclamações pela insuficiência no número de desembargadores, na Relação da Bahia. Além do extenso trabalho a que eram submetidos, com pleitos e querelas remetidas das várias localidades do território, os desembargadores realizaram sucessivos deslocamentos pelos espaços que estavam sob jurisdição do Tribunal, para conduzir devassas, residências e demais investigações. $O$ autor argumenta que "juízes ausentes de Salvador em investigações especiais, atribuições extras de natureza administrativa e um grande número de casos à espera de julgamento combinavam para retardar o processo judicial". Além do considerável número de desembargadores doentes, como ocorreu durante todo o período de funcionamento da instituição (lbid., p. 205).

No século XVIII, após a descoberta do ouro nas Minas do centro-sul da colônia, houve uma extensão da magistratura para o interior da América portuguesa. Com o sucessivo crescimento econômico e populacional daquelas regiões e a exploração aurífera, a vila de São Sebastião do Rio de Janeiro recebeu um novo Tribunal da Relação, criado em 1751 e instituído no ano seguinte. Os pedidos para a implementação de um Tribunal da Relação no sul da América portuguesa começaram a aparecer ainda no início do século XVIII, como o requerimento enviado pelo governador da capitania do Rio de Janeiro, Antonio de Brito Freire e Menezes, em 1718, que reclamou dos problemas enfrentados pela administração da justiça na localidade, sugerindo a criação de uma outra Relação com a mesma alçada do 
Tribunal da Bahia, e jurisdição sobre as capitanias do Rio de Janeiro, São Paulo e Minas Gerais (MELLO, 2018, p. 92-93).

Poucos anos depois, as câmaras da capitania de Minas também enviaram requerimentos ao rei D. João V. Isabelle Mello aponta que a câmara de Vila Rica tratou dos inconvenientes da distância com o Tribunal da Relação da Bahia, afirmando também que uma nova Relação, instituída no centro-sul da colônia, causaria "temor" nos ministros de justiça da região das Minas, e eles passariam a proceder melhor nos negócios da justiça (Ibid., p. 93). Em 1730, as câmaras de Vila Rica e Ribeirão do Carmo, além de expor suas dificuldades em relação ao envio das apelações e agravos à Relação da Bahia, propuseram um auxílio anual de 4.000 e 3.000 cruzados, respectivamente, para auxiliar o custeio da instalação do novo tribunal (WEHLING; WEHLING, 2004, p. 126-127). Ronald Raminelli mostra que em 1744, a vila do Príncipe, também na capitania de Minas, escreveu ao rei, tratando das "vexações de se recorrer à Relação da Bahia" (RAMINELLI, 2017, p. 387).

Segundo Maria José e Arno Wehling, a criação do Tribunal da Relação do Rio de Janeiro está relacionada à "sistemática reafirmação da autoridade régia", que tinha sua definição a partir da alta burocracia portuguesa, onde a justiça ocupava papel estratégico. Os autores argumentam que a criação de um Tribunal para o centro e o sul da Colônia não era apenas o cumprimento de uma reivindicação para aperfeiçoar a justiça na região mineradora, mas um ato político e centralizador do Estado português (WEHLING; WEHLING, 2004, p. 124).

Reafirmando conclusões tomadas por Schwartz, Maria José e Arno Wehling argumentam que a atuação dos Tribunais da Relação não se restringiu à questão judicial, pois a função dos desembargadores abarcou também questões de natureza política e administrativa. A criação da Relação do Rio de Janeiro coincidiu com a mudança de orientação do Estado português, a partir do governo do Marquês de Pombal, caracterizada por uma racionalização do Estado e, no campo jurídico, por uma tentativa de revisão legislativa (lbid., p. 348).

Após a criação da Relação do Rio de Janeiro, o Tribunal da Relação da Bahia teve seu espaço de jurisdição restringido, limitando-se ao território das capitanias de Sergipe Del'Rey, Pernambuco, Itamaracá, Paraíba, Rio Grande do Norte e Ceará. A jurisdição da Relação da Bahia tinha seu limite, ao norte, nas capitanias do Piauí e Maranhão, que juntamente as capitanias do Pará e do Rio Negro, tinham seus pleitos 
enviados diretamente aos tribunais portugueses. A Relação do Rio de Janeiro teve sua jurisdição estendida às demais capitanias do sul da América portuguesa.

Após a vinda da família real para o Brasil, em 1808, houve um significativo crescimento da malha administrativa e jurídica do território. Essa ampliação teve a cidade do Rio de Janeiro, que se tornou eixo do império, como foco principal, mas também foi vivenciada nas outras capitanias. O príncipe D. João instituiu no Rio de Janeiro significativa parte da estrutura administrativa que existia em Lisboa. Foram instaladas na cidade instituições importantes para a manutenção da estrutura administrativa e corporativa da monarquia, como o Desembargo do Paço, a Mesa de Consciência e Ordem, a Intendência Geral de Polícia e a elevação do Tribunal da Relação do Rio de Janeiro à Casa de Suplicação do Brasil.

Além dessas instituições, houve um acréscimo de comarcas e cargos de juízes de fora e ouvidores nas capitanias e vilas da América portuguesa. Entre 1808 e 1821 foram instituídos trinta e oito cargos de juízes de fora, contra treze entre os anos de 1697 e 1808. Ainda no mesmo período foram criadas oito comarcas e trinta e três vilas. Para Arno Wehling, o governo joanino apresentou uma evidente ampliação do Estado, onde antes havia pouca ou total ausência dele. Embora leve em consideração que a ação ocorrida não eliminou o mandonismo das elites locais, aponta que houve alteração na relação de forças entre os interesses locais e autoridades da monarquia. Como resultado, houve significativa extensão da esfera pública (WEHLING, 2007); (WEHLING, 2019).

A capitania de Pernambuco foi uma das regiões da América portuguesa que mais sofreu a expansão de sua estrutura administrativa e jurídica durante o governo joanino. Entre 1808 e 1821, dez vilas foram criadas no território, configurando-se na região que mais teve municipalidades instituídas no período, quatro a mais que a capitania do Rio de Janeiro. Além disso, foi criado um cargo de Juiz de Fora na vila de Goiana, situada na fronteira com a capitania da Paraíba, e a comarca de Pernambuco foi desmembrada duas vezes, dando origem à comarca do Sertão em 1810 e à comarca de Olinda em 1815 (WEHLING, 2007); (SILVA, 2020).

No conjunto dessa ampliação administrativa, destacamos duas decisões estabelecidas pela administração joanina. A primeira, instituída em 1811, foi a determinação de criação de Juntas de Justiça nas capitanias, para diminuir o número de processos e querelas que chegavam aos tribunais superiores. O príncipe alegou 
ciência das dificuldades de se recorrer aos tribunais superiores, e afirmou estar sempre propenso a administrar a justiça com imparcialidade e para facilitar o acesso com brevidade, inteligência e integridade, mandou estabelecer nas capitanias e demais domínios ultramarinos, Juntas de Justiça, compostas pelo "Governador ou Capitão General, pelo Ouvidor e Juiz de Fora". ${ }^{4}$

As Juntas foram incumbidas de ações jurídicas e administrativas semelhantes às aplicadas pelos Tribunais da Relação. No escopo de atuação dessas instituições, estava a possibilidade de conceder cartas de seguro, passar alvarás de fiança e expedir provisões para o procurador da coroa demandar questões sobre fazenda. A Junta também tinha o poder de comutar penas, menos para as galés. Todos os alvarás, cartas e provisões seriam expedidos em nome do príncipe e assinados pelos governadores das capitanias. Caberia também a elas o poder de determinar o número de sujeitos que poderiam atuar como advogados em cada capitania. Os indivíduos flagrados no exercício da função sem terem sido nomeados pelas Juntas, poderiam permanecer até dois meses presos, e em caso de reincidência, poderiam ser expulsos da capitania. ${ }^{5}$

A segunda medida de destaque instituída no governo joanino, foi a criação do terceiro Tribunal da Relação da América portuguesa, instituído na vila de São Luís, capitania do Maranhão, em 13 de maio de 1812. Segundo a historiadora Isabele Mello, desde o final do século XVIII, agentes da administração ultramarina tinham interesse em instituir outra Relação na colônia. Para Mello, o Tribunal da Relação do Maranhão foi instituído pensando não apenas nas solicitações dos súditos, mas na importância política e econômica da região, visto que a localidade vinha passando por transformações deste caráter desde o período pombalino. A autora ainda considera que após a chegada da família real, a região passou por ações diplomáticas com o território da Guiana Francesa, tomando "nova importância para política imperial portuguesa" (MELLO, 2018, p. 96-98).

A invasão francesa ao território de Portugal na Europa deixou os súditos do Estado do Grão-Pará e Maranhão em falta com a justiça régia, pois ambos enviavam

\footnotetext{
${ }^{4}$ CLB. Alvará de 10 de setembro de 1811. Rio de Janeiro: Imprensa Nacional, 1891, p. 105.

${ }^{5}$ As Juntas também teriam o poder de expedir perdões que geralmente eram dados na Sexta-Feira Santa, mas apenas em casos bastante limitados, embora não especificados no a. Não entraram no rol de ações da instituições tratar e punir sobre questões como blasfêmia, moeda falsa, falsidade, testemunho falso, morte cometida traiçoeiramente, ferimentos, propagação de veneno, remédio para abortar, arrombamento de cadeia, incêndio causado de propósito nos templos, procissão, adultério com a mulher levada da casa do marido, incesto, entre outros. Ibid., 105-108.
} 
seus pleitos diretamente aos Tribunais Superiores instituídos no reino. Com a impossibilidade de comunicação com as instituições portuguesas, era imposta uma falta significativa no acesso à justiça para uma parte importante dos súditos do império. Instituir uma Relação na localidade foi também um ato de reparação por parte da coroa, dando possibilidade para a população daquela região continuar exercendo suas prerrogativas de súditos, recorrendo de seus pleitos judiciários.

A composição dos Tribunais da Relação era bastante ampla, especialmente em relação aos cargos de caráter administrativo, fundamentais para o funcionamento das instituições de justiça, como escrivães, meirinhos, contadores e guardas-mores (WEHLING, WEHLING, 2004, p. 189-190). Mas os atores principais dos Tribunais Superiores eram os desembargadores. Como argumenta José Subtil, "o provimento de lugares de magistratura" no Antigo Regime era uma mercê, e não podia ser confundido como "um simples ato administrativo", especialmente aos que ocuparam cargos nos Tribunais Superiores (SUBTIL, 2010, p. 245). Os magistrados nomeados para as Relações ocupavam cargos específicos na estrutura administrativa da instituição, como Chanceler, Desembargador de Agravos e Apelações, Ouvidor Geral do Crime, Ouvidor Geral do Cível, Juiz dos Feitos da Coroa e Fazenda e Procurador dos Feitos da Coroa e Fazenda.

Os regimentos das Relações, apresentados no ato de instalação dos Tribunais, estabeleciam também a existência da função de Governador da Relação, exercida pelo governador da capitania ou vice-rei onde o Tribunal da Relação estivesse instalado, exercendo um cargo que unia instâncias jurisdicionais e administrativas, um elemento característico da burocracia portuguesa. O governador, entre suas funções, era o responsável pelo pagamento dos desembargadores, mas sua principal atividade era supervisionar o trabalho do chanceler e dos outros magistrados (WEHLING; WEHLING, 2004, p. 147). Mas António Manuel Hespanha argumenta que era função das Relações tomar residência ${ }^{6}$ aos governadores e vicereis que terminassem seu mandato, fazendo com que esses indivíduos estivessem sujeitos à sindicância da Relação (HESPANHA, 2010, p. 181-182).

Sobre as funções dos desembargadores dos Tribunais da Relação, em resumo, ao Chanceler, era conferida a função de dirigente da instituição. Em geral,

\footnotetext{
${ }^{6}$ A residência era um exame sobre os procedimentos e atuação dos funcionários régios. Tinha intenção de averiguar a atuação de governadores, juízes de fora, ouvidores, entre outros, no exercício de suas funções (MELLO, 2015, p. 154-155).
} 
era o magistrado mais experiente ou o mais antigo, e tinha poder de substituir o governador em caso de sua ausência. Para o chanceler, eram conferidas a direção administrativa e funções de corregedoria do tribunal, como o controle sobre tabeliães, escrivães e contadores, e sobre o correto funcionamento dos processos que tramitavam na instituição. Aos desembargadores das Apelações e Agravos, competiam matérias de natureza cível e criminal. Despachavam processos e questões que partiam das mais diversas comarcas e precisavam ter conhecimento dos agravos das sentenças dos ouvidores e apelações dos casos cíveis que partiam dos foros inferiores, como os ouvidores, juízes de fora e de órfãos (WEHLING; WEHLING, 2004, p. 147-149).

O Ouvidor Geral do Crime recebia ações criminais novas ou recursos de sentenças advindas dos foros inferiores, mas também podia avocar para si processos e querelas de ouvidores, juízes de fora e ordinários, em um raio de 15 léguas. Ao Ouvidor Geral do Cível, eram dadas competências semelhantes aos ouvidores de comarca, como conceder audiências públicas, receber pleitos de viúvas e órfãos e deviam conhecer todas as ações cíveis novas das cidades e vilas onde a Relação estava estabelecida. Para as Relações do Rio de Janeiro, do Maranhão e de Pernambuco, suas alçadas eram de 150 mil-réis em bens móveis e 120 mil-réis em bens de raiz. Ao Juiz dos Feitos da Coroa e Fazenda, cabia receber ações novas e agravos sobre assuntos fazendários. O Procurador dos Feitos da Coroa devia representar e defender os interesses do Estado nos processos em que a coroa fizesse parte (WEHLING; WEHLING, 2004, p. 150-152).

\section{A CRIAÇÃO DO TRIBUNAL DA RELAÇÃO DE PERNAMBUCO}

O Tribunal da Relação de Pernambuco foi instituído pelo rei D. João VI em 6 de fevereiro de 1821, sendo o quarto e último Tribunal Superior instituído na América pelo governo português. Mas as solicitações dos residentes da capitania para que a coroa instituísse um Tribunal na localidade, separando a região da tutela do Tribunal da Relação da Bahia, iniciaram ainda no século XVII. Segundo Stuart Schwartz, a açucarocracia pernambucana não gostava da intromissão do Tribunal da Bahia em seus assuntos (SCHWARTZ, 2011, p. 188-191). Em 1654 uma decisão régia negou a 
instalação do Tribunal aos pernambucanos. 0 Conselho Ultramarino ${ }^{7}$ alegou que 0 Brasil, naquele momento, não era capaz de suportar duas Relações, e como a solicitação havia sido feita pouco depois da expulsão dos holandeses do território pernambucano, a região necessitava "mais d'armas", do que de ministros de justiça. ${ }^{8}$ Em 1672, a Câmara de Olinda requereu a criação de um Tribunal da Relação em Pernambuco e a criação de um governo-geral centralizado na capitania, mostrando o interesse dos pernambucanos em se separar da tutela judicial e administrativa do governo-geral e do Tribunal da Relação da Bahia.

Os edis da câmara de Olinda argumentaram que era difícil e custoso para os habitantes de Pernambuco e das capitanias de Itamaracá, Paraíba, Ceará e Rio Grande do Norte recorrerem de seus pleitos à Relação da Bahia. A distância e os custos de deslocamento à cidade de Salvador foram apontados como os principais motivos. Também argumentaram que houve um aumento da criminalidade e consequentemente de impunidade em Pernambuco, pois o ouvidor-geral da capitania não era capaz de administrar a justiça em um espaço tão vasto, como era o território que compreendia a comarca de Pernambuco no século XVII. A solicitação também não foi atendida, embora houvesse reconhecimento, por parte da coroa, sobre os diversos problemas que precisavam ser enfrentados pelos súditos que almejavam apelar ao Tribunal da Relação da Bahia. ${ }^{9}$

Após a negativa do pedido da câmara de Olinda datado de 1672, as solicitações para a instalação da Relação de Pernambuco só reapareceram no final do século XVIII, combinadas entre as câmaras das principais vilas da capitania de Pernambuco. Entre os anos de 1795 e 1802, as câmaras de Olinda, Recife, Igarassu e Sirinhaém peticionaram à rainha $\mathrm{D}$. Maria I, solicitando a instalação de um Tribunal da Relação em Pernambuco.

Os pedidos estavam amparados em argumentos semelhantes aos apresentados nas súplicas enviadas no século XVII. Argumentaram sobre as dificuldades de mobilidade para Salvador, tanto por terra, quanto por mar, e os

\footnotetext{
7 O Conselho Ultramarino, criado em 1642, foi um órgão que assumiu posição administrativa e política referente aos assuntos coloniais nos âmbitos civis, jurídicos e militares. Foi responsável por "instar e sugerir" medidas e políticas para conservação dos vassalos e súditos dos territórios ultramarinos, tendo produzido um conjunto substancial de consultas, requerimentos e documentos (MONTEIRO; BICALHO, 2018, p. 225-228).

${ }^{8}$ Arquivo Histórico Ultramarino. Avulsos de Pernambuco. 31 de março de 1654, Caixa 06, Documento 466, f. 02; (CAETANO, 2018, 207-221); (SILVA, 2019, 45-49).

${ }_{9}^{9}$ Arquivo Histórico Ultramarino. Avulsos de Pernambuco. 22 de agosto de 1672, Caixa 10, Documento 960 , f. $02-03$.
} 
elevados custos da viagem. Também argumentaram que aqueles que se aventuravam na empreitada, precisavam estabelecer residência em Salvador, ao menos por algum tempo, ou enviar procuradores, o que aumentava os custos, fazendo que a possibilidade de recorrer dos pleitos, elemento de significativa importância na relação entre os súditos e os monarcas, ficasse restrita a parcela mais abastada da população, e impedida aos mais pobres. Para os edis das câmaras, aliados ao ouvidor da comarca de Pernambuco, o desembargador Antonio Luiz Pereira da Cunha, que almejava ser nomeado chanceler, caso o tribunal fosse instituído, uma Relação em Pernambuco promoveria tranquilidade e felicidade à região, aumentaria a renda dos negócios locais e os desembargadores poderiam fiscalizar melhor o trabalho dos demais magistrados da capitania, melhorando a prática da justiça na localidade. ${ }^{10}$

Em 1799, o governador da capitania da Bahia, Fernando José de Portugal e Castro, respeitado magistrado, tendo sido desembargador no Tribunal da Relação do Porto, foi consultado sobre a criação de uma Relação em Pernambuco (VALIM, 2018, p. 99). Em outubro de 1799, Portugal e Castro alegou que não havia necessidade de uma Relação na localidade, e relativizou os argumentos das câmaras da capitania em relação às distâncias e aos custos daqueles que buscavam recurso em Salvador. Mas o principal argumento levantado pelo governador foi em relação ao custo, que de fato não seria baixo, de instituir uma nova Relação. Além de ser oneroso aos cofres portugueses, argumentou que a colônia não tinha condição de arcar com tais custos naquele momento. Ao final, Portugal e Castro também apontou que a criação de um Tribunal em Pernambuco limitaria o espaço de jurisdição e as rendas do Tribunal da Relação da Bahia, já reduzidos com a instalação do Tribunal da Relação do Rio de Janeiro, em $1752 .^{11}$

O príncipe D. João, regente no trono desde 1793, deixou a decisão sobre instalar ou não a Relação, a cargo do Conselho Ultramarino. Em decisões expedidas a partir de 1802, os membros do Conselho não autorizaram a criação da Relação de

10 Arquivo Histórico Ultramarino. Avulsos de Pernambuco. 29 de dezembro de 1795, Caixa 191, Documento 13189; Arquivo Histórico Ultramarino. Avulsos de Pernambuco. 30 de dezembro de 1795, Caixa 191, Documento 13190; Arquivo Histórico Ultramarino. Avulsos de Pernambuco. 30 de dezembro de 1795, Caixa 191, Documento 13190; Arquivo Histórico Ultramarino. Avulsos de Pernambuco. 3 de fevereiro de 1796, Caixa 192, Documento 13215; Arquivo Histórico Ultramarino. Avulsos de Pernambuco. 15 de janeiro de 1801, Caixa 223, Documento 15091; Arquivo Histórico Ultramarino. Avulsos de Pernambuco. 11 de junho de 1802, Caixa 234, Documento 15834; (CAETANO, 2018, 223244); (SILVA, 2019, p. 49-55).

11 Arquivo Histórico Ultramarino. Avulsos da Bahia. 2 de outubro de 1799, Caixa 215, Documento 15113. 
Pernambuco, argumentando que a medida não era necessária, além de muito custosa. Vendo a interação do ouvidor-geral da comarca Antonio Luiz Pereira da Cunha com as elites da capitania, os conselheiros alegaram que as súplicas não mereciam atenção, pois pareciam querer atender aos interesses particulares do ouvidor. Compreendiam que algumas regiões da capitania passaram por significativo crescimento econômico e populacional, mas a instituição de juízes de fora em algumas vilas seria suficiente para melhorar a administração da justiça no território. ${ }^{12}$

Como argumentamos acima, a chegada da família real no Brasil possibilitou, segundo Arno Wehling, o "adensamento e interiorização da justiça", ou seja, o aumento do número de juízes de fora, comarcas, vilas e tribunais (WEHLING, 2019, p. 20). Aproveitando o crescimento da estrutura administrativa que ocorria na América portuguesa, em 1810, o governador da capitania de Pernambuco, Caetano Pinto de Miranda Montenegro, enviou uma petição a Fernando José de Portugal e Castro, que naquele momento exercia a função de Secretário de Estado dos Negócios do Brasil, e ao príncipe D. João, requerendo a instalação de uma Relação em Pernambuco. O governador solicitava uma Relação com menos desembargadores, para atender as necessidades da localidade e das capitanias vizinhas. Chegou a alegar que renunciaria ao ordenado de governador da Relação, ${ }^{13}$ mas o pedido não foi atendido.

O ministro a quem foi remetida a petição do governador Caetano Pinto de Miranda Montenegro, Fernando José de Portugal e Castro, foi o mesmo que deu parecer contrário à criação do Tribunal em Pernambuco, em 1799. É provável que Portugal e Castro tenha tido posição importante na nova decisão negativa. Contudo, como mostramos acima, mesmo não recebendo o Tribunal da Relação, a capitania de Pernambuco foi acrescida de duas comarcas - a comarca do Sertão (1810) e a comarca de Olinda (1815), ocasionando a chegada de dois novos magistrados para a localidade, como também foi instituído um juiz de fora na vila de Goiana (SILVA, 2020, 25-46).

Alguns anos depois da petição enviada pelo governador Caetano Pinto de Miranda Montenegro, Pernambuco foi palco de um dos principais movimentos de contestação ao poder régio ocorridos no período colonial, a revolução de 1817 . O

${ }^{12}$ Arquivo Histórico Ultramarino. Avulsos de Pernambuco. 11 de julho de 1802, Caixa 234, Documento 15834; (CAETANO, 2018, p. 238-240).

${ }^{13}$ Arquivo Público de Pernambuco. Fundo correspondência para a corte. 2 de julho de 1810. Códice 17. p. 47-57; (CAETANO, 2018, p. 240-245). 
movimento, organizado por civis e militares, assumiu o controle da capitania no dia 6 de março de 1817. Logo após a capitulação e saída do governador Caetano Pinto de Miranda Montenegro do território, instituíram uma república que durou 74 dias, contando com o apoio de clérigos, proprietários rurais e urbanos, e inclusive dos magistrados que estavam em Pernambuco (LEITE, 1988).

Os revolucionários chegaram a estabelecer uma Lei Orgânica. Segundo Marcelo Continentino, a Lei Orgânica da revolução de 1817 constituiu uma ruptura na ordem política portuguesa e estava revestida de uma perspectiva orientada para o futuro, que seria um dos configuradores modernos do conceito de constituição (CONTINENTINO, 2017). Mas graças ao envio de militares do Rio de Janeiro e da Bahia, e contando com a ajuda de senhores de terra da capitania, preocupados com a possibilidade do fim da escravidão e perda de seus poderes de mando, o movimento foi suprimido pela coroa, pautado por forte repressão, com suplícios e castigos sumários, em que padres foram executados. Alguns homens apontados como líderes do movimento, entre eles clérigos, comerciantes e magistrados, como o ouvidor da comarca de Olinda Antonio Carlos Ribeiro de Andrada Machado, foram presos, alguns sumariamente executados e outros remetidos aos cárceres de Pernambuco e da Bahia (LEITE, 1988).

No ano de 1817, o império português precisou atuar perante duas frentes de contestação ao poder monárquico, a revolução sucedida em Pernambuco, e a Conspiração Gomes Freire, ocorrida em Portugal. Esses eventos mostraram as insatisfações com o regime político monárquico português, ainda pautado nas estruturas políticas do Antigo Regime, tendo como referência a centralidade do poder dos monarcas e a falta de atitudes referenciadas em ideias e valores liberais e constitucionais, como estava ocorrendo em outros contextos, tanto na América, quanto na Europa (SCHIAVINATTO, 1999, p. 65-91). Entre o final do século XVIII e o início do século XIX, exemplos de movimentos de contestação social e política despontavam em ambos os lados do Atlântico, como a Independência dos Estados Unidos (1776), a Revolução Francesa (1789), a instituição das Cortes e da Constituição de Cádiz na Espanha (1812), além do franco processo de independência dos territórios americanos que outrora pertenceram à coroa espanhola. 
Essas ideias começaram a ganhar adeptos em Portugal. Os súditos europeus do império português passaram a reclamar da longa permanência da família real no Brasil. Alegaram desprestígio, e sentiam-se preteridos em termos econômicos e políticos com a fixação da coroa e da centralidade administrativa do império, ainda fixada no Brasil, que desde 1815 fora elevado à categoria de Reino Unido de Portugal e Algarve (NEVES, 2016).

Esses elementos foram importantes no desenvolvimento do movimento que instituiu o constitucionalismo em Portugal, iniciado na cidade do Porto em 1820. A Revolução Liberal do Porto, como ficou conhecido o movimento liberal português, foi iniciado por civis, desembargadores do Tribunal da Relação do Porto e comerciantes, além de militares e logo recebeu aderência da população portuguesa. O movimento posicionou-se de forma favorável à introdução de ideias liberais e constitucionais no império, propondo a criação de uma Assembleia Constituinte, formada por membros (deputados) eleitos tanto em Portugal, quanto nos territórios ultramarinos, para preparar a constituição. Mas não romperam com o regime monárquico, mantendo $\mathrm{D}$. João $\mathrm{VI}$ no trono, desde que o rei e os membros da família real aceitassem se submeter à Constituição (ALEXANDRE, 1993).

A notícia do início do Movimento Liberal iniciado na cidade do Porto desembarcou no Rio de Janeiro em setembro de 1820, e em Pernambuco no mês seguinte. Naquela circunstância, Luís do Rego Barreto, governador que assumiu a administração da capitania de Pernambuco após a revolução de 1817, atuava contra uma rebelião que ocorria na Serra do Rodeador, vila de Bonito, interior da capitania, e que fora suprimida pelas forças militares de Recife e Olinda. Ao final daquele ano, uma conspiração baseada nas ideias que serviram de base para a Revolução Liberal do Porto, conduzida por militares estabelecidos em Pernambuco, foi descoberta pelo governador Luís do Rego Barreto. A intenção da conspiração era assassinar o governador, que possuía significativo rol de inimigos em Pernambuco (CABRAL, 2013, p. 143-151). Mesmo descoberta a tempo, e com uma investigação instaurada e conduzida pelo ouvidor da comarca do Recife Antero José da Maia e Silva, para descobrir e prender os conspiradores, havia o temor de que um movimento semelhante ao sucedido em 1817 viesse a ocorrer. A revolução produziu uma memória de atuação dos revolucionários em Pernambuco, assim como as ações de repressão tomadas pela coroa portuguesa. Essa memória permeou os anos 
seguintes e a administração do governador Luís do Rego, que procurou reagir contra os atos que pudessem incendiar a população e dar início a um novo movimento contestatório (BERNARDES, 2006); (CABRAL, 2013).

Enquanto em Pernambuco o governador atuava de forma repressiva contra ações que ameaçavam sua vida e a ordem na capitania, entre dezembro de 1820 e janeiro de 1821, o monarca, seus ministros e conselheiros mais próximos, tomavam ciência dos eventos que ocorriam tanto em Portugal, quanto em Pernambuco e sobre as notícias de possíveis adesões de regiões da América portuguesa ao movimento constitucional iniciado em Portugal. O avanço das ideias constitucionais no Brasil era patente, antes mesmo da corte joanina tomar uma posição sobre sua adesão àqueles preceitos. Notícias chegavam ao Rio de Janeiro tratando das possíveis adesões de regiões do Brasil ao movimento constitucional do Porto, como veio a ocorrer ainda no mês de fevereiro no Pará e na Bahia, que declararam apoio às Cortes constituídas em Lisboa, destituíram os governadores nomeados pelo rei e estabeleceram Juntas Governativas, formadas por membros das elites das próprias localidades (NEVES, 2003); (SCHIAVINATTO, 1999); (LIMA, 2006).

A questão da ordem entrava no campo de preocupações da corte, especialmente depois da chegada ao Rio de Janeiro das notícias sobre as investigações realizadas pelo ouvidor da comarca do Recife e do governador de Pernambuco, sobre a nova conspiração descoberta em dezembro de 1820 . Foi nesse contexto de tensão social e política no Brasil, e sob o receio de uma nova sublevação militar em Pernambuco que o rei D. João VI, em 6 de fevereiro de 1821, expediu um alvará régio, instituindo o Tribunal da Relação na capitania de Pernambuco. No documento, o monarca afirmava estar atendendo uma petição da câmara de Olinda, que requeria uma Relação na localidade devido às dificuldades de se recorrer ao Tribunal da Relação da Bahia, dadas as grandes distâncias, avultadas despesas, interrupção de trabalhos indispensáveis e demais inconvenientes, como as câmaras já haviam argumentado nas petições anteriores.

À Relação de Pernambuco, foi instituído o mesmo Regimento dado à Relação do Maranhão. O espaço de jurisdição do novo Tribunal compreendia, inicialmente, as comarcas da província de Pernambuco - Olinda, Recife e Sertão - e as comarcas das províncias da Paraíba, Rio Grande do Norte e Ceará. A instituição teria a mesma graduação e alçada das Relações já instaladas no Brasil, e como as demais, seria 
presidida pelo governador de Pernambuco, além de composta pelo desembargador chanceler e o mesmo número de desembargadores e oficiais que tinha a Relação do Maranhão. ${ }^{14}$ No alvará, D. João VI alegou ser

\begin{abstract}
"um dos primeiros objetos dos Meus Paternais Cuidados remover os embaraços que possam retardar ou estorvar aos meus fiéis vassalos os recursos que Ihes permitem as Leis na Administração da Justiça, e que lhes afiançam a segurança pessoal, e a dos sagrados direitos de propriedade, que muito desejo manter, como a mais segura base da sociedade civil". ${ }^{15}$ [Grifo nosso]
\end{abstract}

A afirmação apresentada acima pelo rei estava de acordo com o papel designado aos monarcas no Antigo Regime. Na estrutura política do mundo moderno, o rei possuía a suprema iurisdictio, ou seja, o monarca era a fonte de toda a jurisdição do reino. A justiça, como "um dos primeiros objetos" dos seus "paternais cuidados", era um dos principais elementos na relação entre os reis e seus vassalos, e o monarca atuava para conservar e manter o equilíbrio entre os poderes (AGÜERO, 2006, p. 3638). Era função do rei afiançar a justiça, a equidade e a paz, além de estabelecer lei geral para todo o reino. Deveria garantir os direitos constituídos e agir como "árbitro dos conflitos sociais e garante dos equilíbrios estabelecidos" (HESPANHA, 1994, p. 487-489). Com essa afirmação, D. João VI reafirmou o caráter corporativo e jurisdicionalista da monarquia portuguesa, mas introduziu termos como direito de propriedade, segurança pessoal e sociedade civil, já comuns na linguagem política do liberalismo e do constitucionalismo, que começaram a ganhar adeptos na América portuguesa após a eclosão da Revolução do Porto.

Ao instituir o Tribunal da Relação de Pernambuco, D. João VI exercia seu papel de promoção da justiça, fundamental na relação entre os súditos e os monarcas. Mas como argumentou António Manuel Hespanha, é necessário sempre desconfiar das fontes, buscar os sentidos que não estão expostos. ${ }^{16} \mathrm{~A}$ criação da Relação de Pernambuco não foi apenas um ato de benevolência do monarca, atendendo aos apelos dos súditos pernambucanos. Como argumentaram Schwartz, Maria José e Arno Wehling, os Tribunais da Relação introduzidos na América portuguesa foram

\footnotetext{
${ }^{14}$ Coleção Leis do Brasil. Alvará de 6 de fevereiro de 1821, Parte II. Rio de Janeiro - RJ. Imprensa Nacional, 1889, p. 04-05.

${ }^{15}$ Coleção Leis do Brasil. Alvará de 6 de fevereiro de 1821, Parte II. Rio de Janeiro - RJ. Imprensa Nacional, 1889, p. 04-05.

16 Entrevista a Antonio Manuel Hespanha por Alejandro Agüero. 19 de setembro de 2017. In: https://www.youtube.com/watch?v=58liWGdC7bw. Acessado em 23 de abril de 2021.
} 
representantes do poder régio, instituídos para fortalecer os interesses da administração nas localidades (SCHWARTZ, 2011); (WEHLING; WEHLING, 2004). Os desembargadores seriam os representantes do monarca nas partes do império, devendo assim, atuar pelos interesses do rei, garantindo inclusive, ao menos em Pernambuco, onde ações de contestação social eram recorrentes, a integridade do território.

Melhorar a prática da administração da justiça nas localidades que estavam sob a jurisdição do Tribunal Superior era um elemento importante e uma preocupação para a coroa. Mas a necessidade de observar e estar a par das ações dos pernambucanos era latente. Na conjuntura de crise política em que a instituição foi implementada, a decisão de estabelecer a Relação de Pernambuco também foi um projeto de futuro para o império português. Filipe Caetano também argumenta que a instalação da nova Relação pode ser entendida como uma forma de reatar e fortalecer laços com os pernambucanos e demais moradores das capitanias do norte, estremecidos graças aos eventos vivenciados na revolução de 1817 (CAETANO, 2018, p. 261-263). Dito isso, adensar a malha administrativa da América portuguesa com a criação de mais um Tribunal Superior seria uma forma de colocar funcionários régios, escolhidos pela coroa, os desembargadores, para aumentar a vigília sobre um território que já havia dado sucessivas mostras de descontentamento com o regime monárquico.

\section{COMPOSIÇÃO DOS PRIMEIROS DESEMBARGADORES DO TRIBUNAL DA RELA ÇÃO DE PERNAMBUCO}

Após a expedição do alvará que autorizou a criação da Relação de Pernambuco, as primeiras medidas tomadas para pôr a instituição em funcionamento foram a escolha e emissão das cartas de nomeação dos magistrados que deveriam compor do quadro de desembargadores do Tribunal. Os desembargadores da Relação de Pernambuco teriam os mesmos ordenados e vencimentos indicados aos desembargadores da Relação do Maranhão. Os chanceleres receberiam um ordenado de $700 \$ 000$ réis, mais uma propina ${ }^{17}$ de $300 \$ 000$ réis, e os

\footnotetext{
17 O termo "propina" significava "presente ou dom em dinheiro [...], que se dá a alguns oficiais, ministros e lentes por assistência, ou trabalho". Funcionava como uma gratificação passada aos funcionários régios, In: Silva, Antonio de Morais; Bluteau, Rafael. Diccionario da lingua portugueza composto pelo padre D. Rafael Bluteau, reformado, e accrescentado por Antonio de Moraes Silva natural
} 
desembargadores $600 \$ 000$ réis, mais propinas de $300 \$ 000$ réis. ${ }^{18}$ Mas em maio de 1822, um decreto expedido pela Secretaria da Fazenda adicionou uma ajuda de custo de $300 \$ 000$ réis aos desembargadores nomeados para Pernambuco. ${ }^{19}$

Como argumentamos acima, ser nomeado para um cargo na magistratura, especialmente na alta magistratura, era uma mercê, ou seja, uma concessão dada pela coroa àqueles que apresentavam merecimento, e que consequentemente conseguissem estruturar boas alianças que pudessem ajudá-los a chegar aos Tribunais Superiores. Na estrutura política do Antigo Regime, os magistrados tinham um papel significativo, a sociedade moderna era pautada por uma "justiça de juízes", onde a consciência do magistrado era o balizador das decisões justas e morais (GARRIGA, 2013, p. 43-46). No exercício de suas funções, esses indivíduos eram imbuídos de jurisdição, que significava que tinham "o poder de dizer o direito". Tal estrutura de organização concebia o magistrado como "o bom julgador", baseado na ideia moral do indivíduo virtuoso, e enquanto autoridades jurisprudentes, com poder de dizer o direito, eram responsáveis pela manutenção da justiça, da prática da equidade e do bom desempenho das instituições (SLEMIAN, 2014, p. 73).

Os magistrados, além de incutidos de iurisdictio, eram tidos como "os prudentes", exercendo funções como "produtores de saber social e político", e "mediadores de conflitos" (HESPANHA, 1994, p. 502) (Id., 2001, p. 1189) (BARRETO; HESPANHA, 1993, p. 130). Como intermediários na relação entre os súditos e os monarcas, além de subordinados ao rei, eram representantes de sua autoridade, exerciam o poder delegado a eles em seu nome, suas atuações eram tidas como extensão da autoridade e do poder do monarca (HESPANHA, 1994, p. 498-502).

Para a inserção na magistratura, era obrigatória a formação universitária, que em Portugal era oferecida pela Universidade de Coimbra. O curso jurídico de Coimbra era dividido em duas especialidades, cânones e leis. Stuart Schwartz argumenta que os ingressantes preferiam cursar a especialização em cânones, porque poderiam atuar tanto na justiça eclesiástica quanto na justiça civil (SCHWARTZ, 2011, p. 78).

do Rio de Janeiro, v. 2. Lisboa: Simão Tadeu Ferreira, 1789, p. 515. https://www.bbm.usp.br/pt$\mathrm{br} /$ dicionarios/diccionario-da-lingua-portugueza-recompilado-dos-vocabularios-impressos-ate-agora-enesta-segunda-edi\%C3\%A7\%C3\%A3o-novamente-emendado-e-muito-acrescentado-por-antonio-demoraes-silva/?page_number=1398\#dic-viewer. Acessado em 22 de abril de 2021.

${ }^{18}$ Coleção Cartas de Lei, Alvarás, Decretos e Cartas Régias do Brasil. Alvará de 13 de maio de 1812. Rio de Janeiro - RJ. Imprensa Nacional, 1889, pp. 11-12.

${ }^{19}$ Coleção das Decisões do Governo do Império do Brasil de 1822. Decisão da Secretaria da Fazenda, 22 de maio de 1822. Rio de Janeiro - RJ. Imprensa Nacional, 1887, p. 37. 
Mas segundo Nuno Camarinhas, a partir da década de 1760 a escolha pelo curso de direito civil (leis) suplantou o interesse pela formação em direito canônico (CAMARINHAS, 2010, p. 240).

Os desembargadores nomeados para o Tribunal da Relação de Pernambuco seguiram a mudança de orientação apontada por Camarinhas. Entre os magistrados que tomaram posse na Relação de Pernambuco entre 1822 e 1840, e cursaram a Universidade de Coimbra entre 1760 e 1825, quarenta e cinco deles, totalizando 83\% do corpo total de desembargadores nomeados, tiveram formação em leis. Apenas quatro deles, totalizando $8 \%$ desses magistrados, formaram-se em Cânones. Até o momento, não identificamos a especialidade seguida por quatro dos desembargadores, e apenas um deles teria cursado as duas especialidades (TRIBUNAL DE JUSTIÇA DE PERNAMBUCO, 2005) (LAGO, 1978).

Gráfico 1 - Formação dos desembargadores em Leis e Cânones (1822-1840)

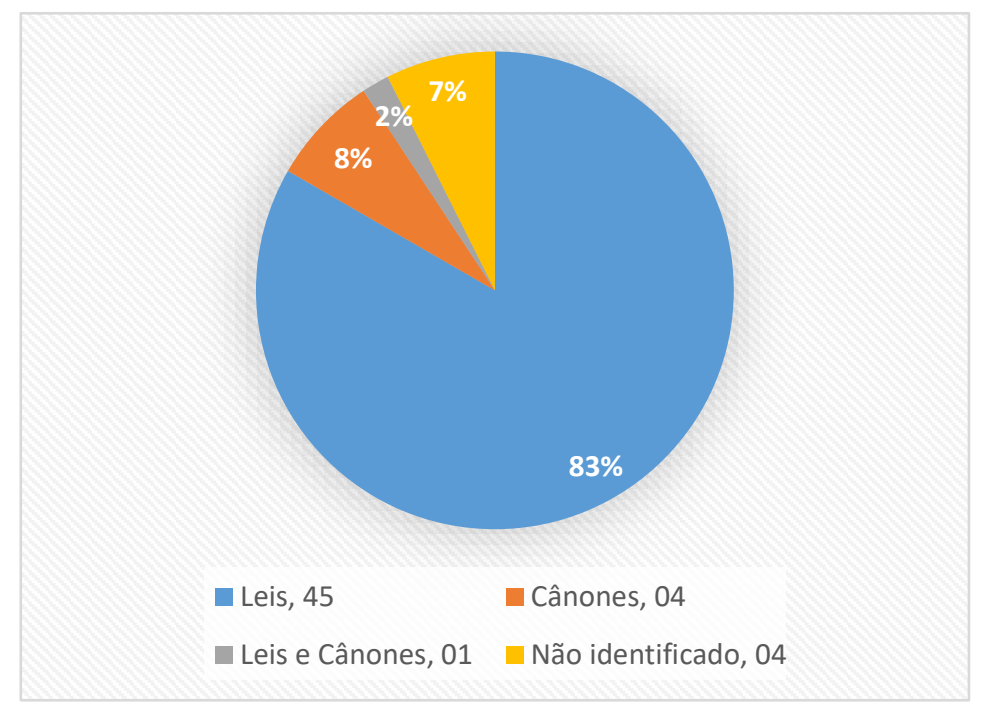

Fonte: Pernambuco, Tribunal de Justiça. Memorial da Justiça - Livro de Compromissos e Posse do Tribunal da Relação de Pernambuco: (1822-1882). Recife: Tribunal de Justiça de Pernambuco, 2005.

Em relação à origem geográfica, ou seja, as localidades de onde partiram os magistrados, observamos que $41 \%$ dos desembargadores eram procedentes da capitania da Bahia. Eduardo José Borges argumenta que as elites baianas não mediram esforços para enviar seus filhos a Coimbra. Segundo o autor, no século XVIII, a quantidade de estudantes da Bahia chegou a superar os advindos de cidades portuguesas, ficando apenas atrás de Lisboa e Porto (BORGES, 2018). Muitos filhos das elites locais das capitanias do Rio de Janeiro e Minas Gerais também foram 
enviados para realizar os cursos jurídicos em Coimbra. As capitanias de Minas Gerais e Rio de Janeiro estavam representadas no quadro de composição dos desembargadores do tribunal, totalizando $11 \%$ e $9 \%$ dos magistrados, respectivamente. Também identificamos que 13\% dos magistrados eram oriundos de cidades e vilas de Portugal (TRIBUNAL DE JUSTIÇA DE PERNAMBUCO, 2005); (LAGO, 1978). Um dos desembargadores portugueses, João Ferreira Sarmento Pimentel, que estava entre os primeiros nomeados para compor o quadro do Tribunal, após a declaração de independência, alegou que não poderia servir no Brasil por não concordar com a separação política, e retornou a Portugal (TRIBUNAL DE JUSTIÇA DE PERNAMBUCO, 2005, p. 113).

Gráfico 2 - Origem geográfica dos desembargadores da Relação de Pernambuco (1822-1840)

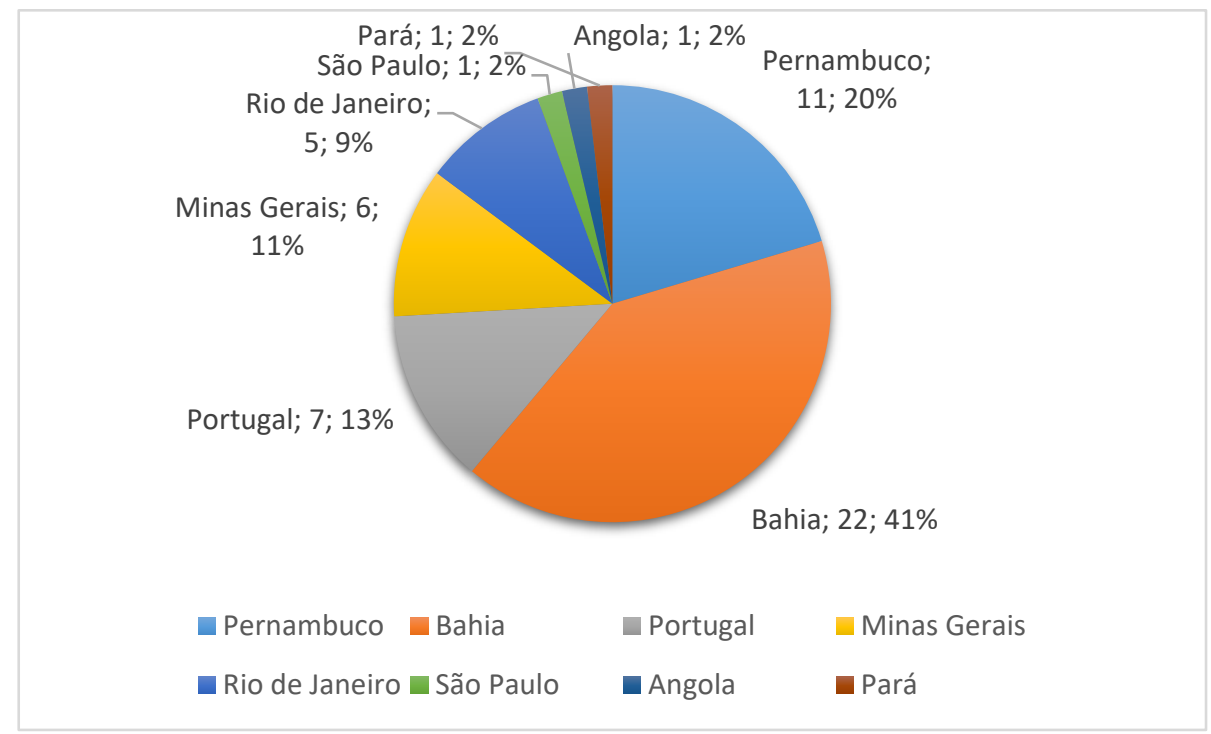

Fonte: Pernambuco, Tribunal de Justiça. Memorial da Justiça - Livro de Compromissos e Posse do Tribunal da Relação de Pernambuco: (1822-1882). Recife: Tribunal de Justiça de Pernambuco, 2005.

Os dados coletados também mostram que o quantitativo de pernambucanos que serviram na Relação de Pernambuco, totalizando 11 desembargadores, ou seja, $20 \%$ do quadro total, foi superior aos que ocuparam os mesmos cargos nas Relações da Bahia e do Rio de Janeiro, onde os pernambucanos tiveram pouca participação, quando comparados com os magistrados oriundos das capitanias da Bahia, Rio de Janeiro e Minas (SCHWARTZ, 2011, p. 362-379); (WEHLING; WEHLING, 2004, p. 618-623). Famílias importantes da localidade, como os Cavalcanti de Albuquerque, Gama e Maciel Monteiro, detentoras de engenhos e atuantes tanto no comércio 
quanto na produção de açúcar, conseguiram introduzir seus filhos na magistratura superior.

No mencionado alvará de 6 de fevereiro de 1821, estava explicitado que os magistrados nomeados para o Tribunal de Pernambuco deveriam ter "servido em lugares de segunda entrância". A entrância significava o início da magistratura. Lugares de segunda entrância eram as cidades ou vilas que eram cabeças de comarca, ou seja, a sede da comarca, em geral, também era o lugar de morada e fixação do ouvidor. Os lugares de primeira entrância eram denominados os que não eram cabeça e sede de comarca (CAMARINHAS, 2010, p. 22).

Gráfico 3 - Quantitativo de postos de magistratura por onde passaram os desembargadores (1822-1840)

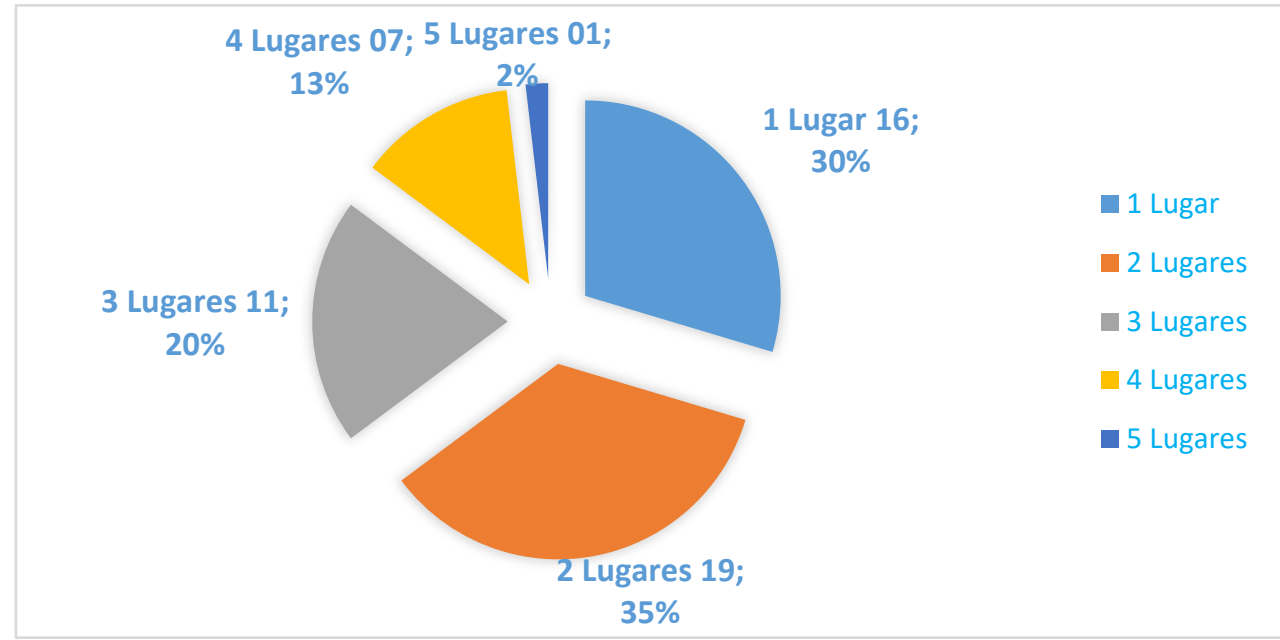

Fonte: Pernambuco, Tribunal de Justiça. Memorial da Justiça - Livro de Compromissos e Posse do Tribunal da Relação de Pernambuco: (1822-1882). Recife: Tribunal de Justiça de Pernambuco, 2005.

Esse elemento indicava a preocupação da coroa com a escolha de magistrados experientes, e que já tivessem atuado em localidades importantes, para ocupar os assentos de desembargadores na nova Relação. A coroa requeria magistrados experientes para exercerem a função no Tribunal de Pernambuco. Na prática, entre 1822 e 1840, o Tribunal recebeu assento de magistrados com significativa experiência, ou seja, que passaram por vários postos em localidades consideradas importantes na América portuguesa. Dezenove magistrados, contabilizando $35 \%$ deles, atuaram em no mínimo dois postos de magistratura, com ouvidores ou juízes de fora, antes de ingressarem na Relação de Pernambuco. Dos cinquenta e quatro magistrados que foram nomeados para o tribunal no período 
analisado, 11 deles, totalizando $20 \%$, tomaram assento no Tribunal após terem passado por no mínimo três outros postos na magistratura.

Também é possível perceber que dezesseis magistrados, totalizando $30 \%$ do quadro total, foram introduzidos na magistratura superior com pouca experiência, tendo atuado apenas em um cargo antes de ascender ao Tribunal da Relação de Pernambuco. O desembargador Luiz Francisco de Paula Cavalcanti de Albuquerque foi primeiro o magistrado nomeado para a Relação de Pernambuco após ter ocupado apenas um cargo de juiz de fora, em uma vila de primeira entrância, na capitania do Ceará. O magistrado era membro de uma das mais destacadas famílias de Pernambuco, e assumiu o cargo no Tribunal da Relação em 1824, após nomeação do imperador D. Pedro I. Entre os membros da família Cavalcanti de Albuquerque, tanto Luiz Francisco, quanto seus irmãos, ocuparam cargos importantes na política imperial, foram aliados de $\mathrm{D}$. Pedro I no momento da independência, e atuaram favoravelmente ao imperador durante a repressão a Confederação do Equador, em 1824 (CADENA, 2013).

Outro ponto que chamou atenção foi o fato de alguns magistrados nomeados já terem experiência nas Relações, como os desembargadores Antonio José Osório de Pina Leitão, aposentado da Relação da Bahia em 1818, e reinserido na magistratura em 1821, e Francisco Affonso Ferreira, pernambucano, desembargador da Relação da Bahia e transferido para a Relação de Pernambuco em 1822. Na implementação dos Tribunais da Relação do Rio de Janeiro e Maranhão, percebemos que os chanceleres, ou seja, os magistrados que deveriam presidir os Tribunais, foram os advindos de outros Tribunais Superiores (MELLO, 2015, p. 196-197). O primeiro chanceler nomeado para o Tribunal da Relação do Maranhão, o desembargador Antonio Rodrigues Vellozo de Oliveira, já havia sido desembargador da Relação do Porto (1800), Casa de Suplicação (1807), ${ }^{20}$ e no momento de sua nomeação para presidir o Tribunal do Maranhão, servia no Desembargo do Paço do Brasil. ${ }^{21}$ Como ocorreu com Lucas Antonio Monteiro de Barros, André Alves Ribeiro e Cirne e Francisco José de Freitas, que assumiram os cargos de chanceler da Relação de Pernambuco no primeiro reinado (1822-1831), e antes ocuparam postos na Relação

\footnotetext{
${ }^{20}$ CAMARINHAS, Nuno. Memorial de Ministros - letrados e lugares de letras, Portugal e Ultramar, 1620-1830. https://memorialdeministros. weebly.com/resultado-letrados.html?cbResetParam=1\&IDJuiz=3915. Acessado em 28 de dezembro de 2020.

${ }^{21}$ BN - Hemeroteca Digital. Gazeta do Rio de Janeiro, 13 de maio de 1812, p. 11.
} 
da Bahia e na Casa de Suplicação do Brasil (TRIBUNAL DE JUSTIÇA DE PERNAMBUCO, 2005, p. 111-124).

Além da experiência em sucessivos cargos na magistratura, a coroa, ao menos no início, preocupou-se em escolher magistrados que tivessem atuado nos locais onde o Tribunal da Relação teria jurisdição, compondo um quadro de magistrados experientes para atuar no campo jurídico, político e administrativo. Como exemplos, Antonio José Osório de Pina Leitão, primeiro Ouvidor Geral do Crime da Relação, fora aposentado da Relação da Bahia e reinserido na magistratura. Atuou na Relação da Bahia quando o Tribunal recebeu os suspeitos e acusados de participação e liderança na revolução de 1817 (TRIBUNAL DE JUSTIÇA DE PERNAMBUCO, 2005, p. 111). Francisco Affonso Ferreira havia sido ouvidor da comarca do Recife durante a revolução. Era pernambucano e tinha significativo conhecimento das elites locais (TRIBUNAL DE JUSTIÇA DE PERNAMBUCO, 2005, p. 114).

O desembargador Bernardo José da Gama, também natural de Pernambuco (TRIBUNAL DE JUSTIÇA DE PERNAMBUCO, 2005, p. 112), foi um favorável ao príncipe D. Pedro, e até escreveu um manifesto em seu favor, intitulado "Memória Sobre as Principais Cauzas, Por Que Deve o Brazil Reassumir Seus Direitos e Reunir as Suas Províncias - Offerecida ao Príncipe Real", publicado na imprensa do Rio, em janeiro de 1822. Como argumentou Evaldo Cabral de Mello, Gama atuou na deposição da Junta Governativa de Pernambuco, comandada por Gervásio Pires Ferreira, durante os conflitos do processo de independência em Pernambuco (MELLO, 2014, p. 65-112). Em 1823, após assumir como deputado na Constituinte, assim como outros desembargadores da Relação de Pernambuco o fizeram, foi apontado pelo Correio do Rio de Janeiro como o "amigalhão" do imperador, e que referendava as "abusivas" intervenções de D. Pedro I no legislativo. ${ }^{22}$

O segundo chanceler da Relação de Pernambuco, André Alves Ribeiro e Cirne, que tomou posse em 1824, após Lucas Antonio Monteiro de Barros se licenciar do Tribunal para exercer suas funções legislativas na Constituinte de 1823, havia ocupado o cargo de ouvidor da comarca da Paraíba, e fora o magistrado responsável por produzir a devassa sobre os participantes da revolução de 1817 naquela capitania.

22 BN - Hemeroteca da Biblioteca Nacional. Jornal Correio do Rio de Janeiro, n. 72, 25 de outubro de 1823. 
Antes disso em 1815, chegou a fazer parte da Junta de Governo da Paraíba, instalada após a morte do governador Antonio Caetano Pereira (TRIBUNAL DE JUSTIÇA DE PERNAMBUCO, 2005, p. 116) (LAGO, 1978, p. 36).

Em resumo, a escolha dos magistrados que ocuparam os cargos de desembargadores no Tribunal da Relação de Pernambuco, ao menos nos primeiros anos de atuação da instituição, período da pesquisa, não foi aleatória ou seguiu apenas caráter técnico, ou seja, não foram apenas as qualidades de um bom magistrado que serviram de guia para a escolha e nomeação deles. A coroa preocupou-se em enviar para a Relação de Pernambuco, magistrados com conhecimento da localidade, dos sujeitos e grupos políticos que ficariam sob a jurisdição da instituição.

\section{CONSIDERAÇÕES FINAIS}

O Tribunal da Relação de Pernambuco foi instituído para reafirmar os laços de afinidade entre os súditos pernambucanos e o monarca, que agiu pautado pelos seus "paternais cuidados", mas também foi uma forma de manter o olhar da administração régia sobre um território que já havia se insurgido contra os valores monárquicos vinculados ao Antigo Regime português. Para tanto, a coroa portuguesa buscou compor a instituição de magistrados com experiência na administração da justiça, que atuaram em lugares de segunda entrância, ou seja, lugares de destaque político e social das localidades e conhecedores do território em que atuariam como desembargadores. A instituição foi instalada em 13 de agosto de 1822, e a partir dessa data, suas diligências na província de Pernambuco foram bastante ampliadas.

Além da competência de natureza jurisdicional comuns e devidas aos Tribunais no Antigo Regime - análises dos processos, querelas, apelações, agravos, petições, prorrogações de cartas de seguro e demais questões concernentes ao universo jurídico - os desembargadores do Tribunal de Pernambuco foram diversas vezes requisitados em busca de opiniões e soluções sobre os aspectos administrativos da província de Pernambuco. Como na administração das aldeias indígenas, na instalação, modificação e extinção de instituições de caráter jurídico e administrativo da província e no aumento de soldo dos militares. O Tribunal da Relação de Pernambuco também assumiu a administração da cadeia do Recife, e ao 
Ouvidor Geral do Crime foi dada a competência de condução das ações de polícia e segurança pública. Os magistrados também foram convidados a opinar sobre as formas de condução das questões jurídicas e a conduta de magistrados dos foros situados abaixo do Tribunal da Relação, questões que no Antigo Regime, eram competência do Desembargo do Paço.

As opiniões e proposições dos magistrados do Tribunal da Relação foram apresentadas aos requisitantes na forma de pareceres. A emissão de pareceres, despachados a pedido dos presidentes de província, conselho de governo e demais autoridades locais, foi um dos principais atributos dos desembargadores. O chamamento dos magistrados à atuação política e administrativa nos primeiros anos do Império do Brasil (1822-1840), aponta para o quanto os elementos da cultura jurisdicional moderna ainda permearam a estrutura política e burocrática do Estado brasileiro (SLEMIAN; GARRIGA, 2013), e o quanto essas temáticas ainda precisam ser pesquisadas e discutidas.

Schwartz, Arno e Maria José Wehling já haviam apontado em seus trabalhos que o campo de ação dos magistrados das Relações da Bahia e Rio de Janeiro fora bastante amplo. No desenvolvimento de nossa pesquisa, temos observado que esse espaço de atuação e jurisdição alargadas, foi dado ao Tribunal e algumas vezes cobrada pelos desembargadores e demais membros da instituição, ações que na maioria dos casos, foram pautadas por conflitos. A chegada do Tribunal da Relação, uma instituição de significativo poder e importância em Pernambuco, local de elites orgulhosas das suas conquistas e poderes, mesmo sendo amplamente demandado, abriu mais um campo de conflitos institucionais, jurídicos e políticos que ao serem analisados e discutidos, como em outras províncias no Império do Brasil, nos ajudam a entender o processo de formação do Estado brasileiro.

\section{REFERÊNCIAS}

ALEXANDRE, Valentim. Os sentidos do império: questão nacional e questão colonial na crise do Antigo Regime português. Lisboa: Edições Afrontamento, 1993.

AGÜERO, Alejandro. Las categorías básicas de la cultura jurisdiccional. In: SARIÑENA, Marta Lorente. De justicia de jueces a justicia de leyes: hacia la España de 1870. Madrid: Consejo General del Poder Judicial, 2006. 
BERNARDES, Denis. O patriotismo constitucional: Pernambuco,1820-1822. São Paulo: Editora da UFPE; HUCITEC; FAPESP, 2006.

BICALHO, Maria Fernanda; MONTEIRO, Nuno Gonçalo. As instituições civis da monarquia portuguesa na Idade Moderna. In: BARRETO, Ângela Xavier; PALOMO, Federico; STUMPF, Roberta. Monarquias Ibéricas em Perspectiva Comparada (séculos XVI-XVIII): dinâmicas imperiais e circulação de modelos políticoadministrativos. Lisboa: ICS - Imprensa de Ciências Sociais, 2018.

BICALHO, Maria Fernanda; ASSIS, Virginia Maria Almoedo; MELLO, Isabele de Matos Pereira (Org.). Justiça no Brasil Colonial: agentes e práticas. São Paulo: Alameda Casa Editorial, 2017.

BORGES, Eduardo Santos. Mobilidade social ascendente e percurso profissional dos desembargadores baianos do século XVIII. Tempo, Niterói, v. 24, n. 01, p. 140-160, jan./abr. 2018.

CABRAL, Flávio Gomes. Conversas reservadas: vozes públicas, conflitos públicos e rebeliões em Pernambuco no tempo da independência do Brasil. Rio de Janeiro: Arquivo Nacional, 2013.

CADENA, Paulo Henrique Fontes. "Ou há de ser Cavalcanti, ou há de ser cavalgado": trajetórias políticas dos Cavalcanti de Albuquerque (Pernambuco, 18011844). Recife: Editora da UFPE, 2013.

CAETANO, Antonio Filipe Pereira. Entre súditos e magistrados: administração da justiça nas capitanias do norte (1789-1821). Maceió - AL: Edufal: Imprensa Oficial Graciliano Ramos, 2018.

CAMARINHAS, Nuno. Juízes e administração da justiça no Antigo Regime: Portugal e o império colonial, séculos XVII e XVIII. Lisboa: Fundação Calouste Gulbenkian, 2010.

CAMARINHAS, Nuno. Os desembargadores no Antigo Regime (1640-1820). In: SUBTIL, José. Dicionário de Desembargadores (1640-1834). Lisboa: Editora da Universidade Autónoma de Lisboa, 2010.

CAMARINHAS, Nuno. A Casa de Suplicação nos finais do Antigo Regime (17901810). Cadernos do Arquivo Municipal, Lisboa, v. 02, n. 02, p. $223-241$, jul./dez. 2014.

CAMARINHAS, Nuno. Lugares Ultramarinos. A construção do aparelho judicial no ultramar português da época moderna. Análise Social, Lisboa, v. LIII, n. 226, p. 136160, jan./abr. 2018.

CONTINENTINO, Marcelo Casseb. Tempos de Constituição: perspectivas e paradoxos da Lei Orgânica da Revolução Republicana de 1817. Revista IHGB, Rio de Janeiro, a. 178(475), p. 15-42, set./dez. 2017. 
GARRIGA, Carlos. Os limites do reformismo bourbônico: a propósito da administração da justiça na América espanhola. Almanack, Guarulhos, n. 6, p. 38-60, jul./dez. 2013.

HESPANHA, António Manuel. Antigo Regime nos trópicos? Um debate sobre o modelo político do império colonial português. In: FRAGOSO; João; GOUVÊA, Maria de Fátima. Na trama das redes: política e negócios no império português, séculos XVI-XVIII. Rio de Janeiro: Civilização Brasileira, 2010.

HESPANHA, António Manuel. Às vésperas do Leviathan: instituições e poder político - Portugal - séc. XVII. Coimbra: Almedina, 1994.

HESPANHA, António Manuel; XAVIER, Ângela Barreto. A representação da sociedade e do poder. In: HESPANHA, António Manuel (coord.). História de Portugal: O Antigo Regime (1620-1807). Lisboa: Editorial Estampa, 1993. v.4

HESPANHA, António Manuel. Entrevista a Antonio Manuel Hespanha por Alejandro Agüero. 19 de setembro de 2017. In: https://www.youtube.com/watch?v=58ljWGdC7bw. Acessado em 23 de abril de 2021.

LAGO, Coronel Laurenio. Supremo Tribunal de Justiça e Supremo Tribunal Federal: dados biográficos 1828-1978. Rio de Janeiro: Biblioteca do Exército Editora, 1978.

LEITE, Glacyra Lazzari. Pernambuco 1817: estrutura e comportamentos sociais. Recife: Massangana, 1988.

LIMA, Oliveira. D. João VI no Brasil. Rio de Janeiro: Topbooks, 2006.

MELLO, Isabele Matos. Instâncias de poder \& justiça: os primeiros tribunais da Relação (Bahia, Rio de Janeiro e Maranhão). Tempo (UFF), Niterói, v. 24, n. 01, p. 89-115, jan./abr. 2018.

MELLO, Isabele de Matos. Magistrados a serviço do rei: os ouvidores e a administração da justiça na comarca do Rio de Janeiro. Rio de Janeiro: Arquivo Nacional, 2015.

MENEZES, Jeannie Silva. A práxis judicial em tempos coloniais: construções teóricas e práticas de poder e autoridade nas dinâmicas da justiça nos mundos americanos (sécs. XVI-XIX). Recife: Editora da UFRPE, 2019.

NEVES, Lúcia Maria Bastos. Corcundas e constitucionais: a cultura política da Independência. Rio de Janeiro: Revan: FAPERJ, 2003.

NEVES, Lucia Maria Bastos. Reino Unido: uma coroa entre a Europa e a América. Revista do IHGB, Rio de Janeiro, a. 177(470), p. 173-192, jan./mar. 2016.

RAMINELLI, Ronald. O poder político das câmaras. In: FRAGOSO, João; MONTEIRO, Nuno Gonçalo (Org.). Um reino e suas repúblicas no Atlântico: comunicações políticas entre Portugal, Brasil e Angola nos séculos XVII e XVIII. Rio de Janeiro: Civilização Brasileira, 2017. 
SCHIAVINATTO, lara L. Franco. Pátria Coroada: o Brasil como corpo político autônomo, 1780-1831. São Paulo: Unesp, 1999.

SCHWARTZ, Stuart. Burocracia e Sociedade no Brasil Colonial: o Tribunal Superior da Bahia e seus desembargadores 1609-1751. São Paulo: Companhia das Letras, 2011,

SILVA, Jeffrey Aislan Souza. "Uma nova Relação na capital do governo de Pernambuco, por evitar a eternizações dos pleitos": as câmaras e os pedidos para a instalação de um Tribunal da Relação na capitania de Pernambuco (SÉCS. XVII E XVIII). Revista Documentação e Memória/TJPE, Recife, PE, v. 4, n. 8, p. 39-58, jan./dez. 2019.

SILVA, Jeffrey Aislan Souza. "Sobre a necessidade de criar" comarcas: o governo da justiça em Pernambuco no período Joanino (1804-1817). Saeculum: Revista de História, João Pessoa, v. 25, n. 42, p. 25-46, jan./jul. 2020.

SLEMIAN, Andréa; GARRIGA, Carlos. Em trajes brasileiros: justiça e constituição na América ibérica (c. 1750-1850). Revista de História (USP), n. 169, p. 181-221, jul./dez. 2013.

SLEMIAN, Andréa. A primeira das virtudes: justiça e reformismo ilustrado na América portuguesa face à espanhola. Revista Complutense de Historia de América (UCD), Madrid, v. 40, n. 01, p. 69-92, jan./dez. 2014.

SIMÕES, Mariane Alves. Entre o juiz ordinário e o juiz de fora: a execução da justiça local e as ações cíveis de Mariana na primeira metade do século XVIII. 2020. 316 f. Tese (Doutorado em História) - Instituto de Ciências Humanas, Universidade Federal de Juiz de Fora, 2020, p. 84-112.

SUBTIL, José. O Desembargo do Paço (1750-1833). Lisboa: Universidade Autónoma de Lisboa, 1996.

TESTOS, Jorge Veiga. Organização judiciária e administração da justiça no Portugal Filipino: a "reformaçam da justiça" de Filipe I de Portugal (1582). In: BECK, Laura; SOLLA, María Julia (Org.). Estudios Luso-Hispanos de Historia del Derecho / Estudos Luso-Hispanos de História do Direito. Madrid, Editorial Dykinson, 2018.

TRIBUNAL DE JUSTIÇA DE PERNAMBUCO. MEMORIAL DA JUSTIÇA. Livro de Compromissos e Posse do Tribunal da Relação de Pernambuco: (1822-1882). Recife: Tribunal de Justiça de Pernambuco, 2005.

WEHLING, Arno e WEHLING, Maria José. Direitos e Justiça no Brasil Colonial: o Tribunal da Relação do Rio de Janeiro (1752-1808). Rio de Janeiro: Editora Renovar, 2004

WEHLING, Arno. Estado, governo e administração no Brasil Joanino. Revista do IHGB, Rio de Janeiro, v. 436, p. 75-93, 2007. 
WEHLING, Arno. A aclamação de d. João VI - o rei e o reino Reconfigurar a corte / (Re)construir o Estado: o horizonte de expectativas no Brasil do Reino Unido. Revista do IHGB, Rio de Janeiro, v. 479, p. 13-48, jan./abr. 2019. 